\title{
Regional solar conditions in the context of sustainable development
}

\author{
Joanna Rudniak,* \\ Czestochowa University of Technology, Faculty of Infrastructure and Environment, ul. Brzeźnicka \\ 60a, 42-200 Częstochowa, Poland
}

\begin{abstract}
The realization of the principles of sustainable development in the Silesia Voivodeship assumes, among others, a low-emission economy and the implementation of renewable energy sources e.g. by increasing the use of solar energy for yield of heat and electricity. The article presents perspectives for solar energy obtaining and the potential of this renewable energy source in the region. It was pointed out, that due to the specificity of the place, the influence of factors limiting the availability of solar radiation such as: air pollutants emitted to the atmosphere, local episodes, weather anomalies, cannot be neglected. Fulfilling the priorities of sustainable development can significantly contribute to improving the quality of atmospheric air, and thus improve the availability of solar radiation in the Silesia Voivodeship.
\end{abstract}

\section{Introduction}

The issues of social, economic and technological development are closely linked to the permanent increase in energy demand. However, currently energy obtaining causes the significant negative impact on the environment and climate. The conscious management of energy resources should be related to its consumption reducing and improving efficiency of energy conversion [1]. Therefore, in the rational management of environmental resources, it is essential to consider the requirements of sustainable development, which was defined as: „development that meets the need of the present without compromising the ability of future generations to meet their own needs", and is considered on three areas: the environment, the society, the economy [2]. Effective use of existing resources, closely linked to environmental protection and minimization of its degradation, is are part of the implementation of the principle of sustainable development also in the Silesia Voivodeship [3]. Achieving of energy sustainable development is possible through proper planning and rational energy management, which takes into account the use of renewable energy sources, and their implementation could reduce negative impacts on the environment and improving its quality $[1,3]$. Among the renewable energy sources, the use of solar energy provides also a potential opportunity for heat and electricity obtaining, and it is now becoming more popular for meeting the energy needs of hospital, educational or recreational facilities, collective housing, as well as among individual recipients.

* Corresponding author: joa@is.pcz.czest.pl 


\section{Characteristics of the region}

The Silesia Voivodeship, as one of the sixteen in Poland, according to the current database of the Central Statistical Office (GUS) [4], has an area of 12,33 thousand square kilometres (3,9\% of the country's area). It has 4,56 million inhabitants (11,9\% of the population) and is the most densely populated area of the country. The region has also the highest urbanization rate of $77,3 \%$ (the average is $60,5 \%$ ). The area of the Silesia Voivodeship (Fig.1.) is divided into four subregions: Northern, Southern, Central and Western [5].

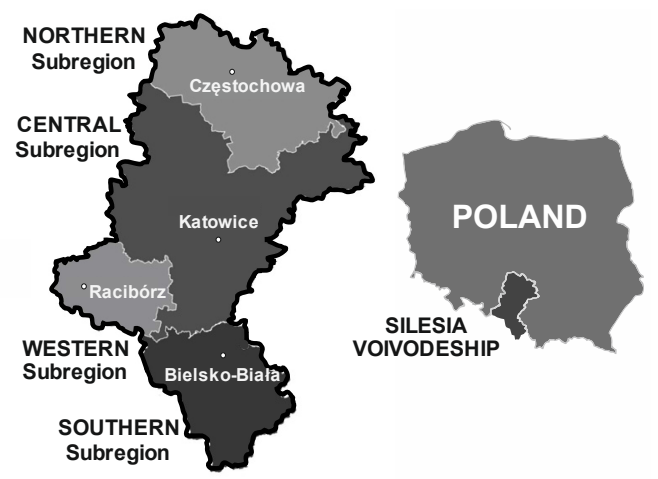

Fig. 1. Subregions of the Silesia Voivodeship / own study based on [5].

Based on this division, activities for the development of the Silesia Voivodeship and its subregions, as well as integrated strategic planning, are carried out. These are among others: The Regional Operational Program of the Silesia Voivodeship for the years 2014-2020 [6], The Spatial Development Plan of the Silesia Voivodeship 2020+ [5], The Strategy for the Development of the Silesia Voivodeship ,Śląskie 2020+” [7].

The vision of the development of the Silesia Voivodeship is to lead, among others, to: achieving last and high competitiveness of the region, as an important and attractive place in Europe, and also creating conditions to implementing the sustainable development principles, as well as using the potential of renewable energy sources and the low-emission economy. The Silesia Voivodeship has a chance to be a region that uses existing economic and environmental potentials, while respecting the principles of sustainable development $[3,5]$. Growth of small distributed energetics, based on renewable sources, and improvement of energy security should aim at increasing the share of energy production from renewable sources and the construction of small generating units in places with the most privileged conditions to use specific environmental resources $[3,5,7]$.

The energy demand in civil engineering, as a necessity to supply electricity and heat, can increasingly be implemented by using renewable energy sources. Objects such as: singlefamily or multi-family residential buildings, industrial or public buildings of various purposes, are characterized by different specificity of energy needs, hence the choice of the most appropriate energy supply solution should take place with special consideration of their needs. Individual conditions determining the potential of renewable energy sources in a particular location also have an impact on the energy availability of a given source and the possibility of its use.

The priority of the sustainable development, such as increasing the share of energy from renewable energy sources, can be achieved by using the available solar potential. Solar energy resources can be defined as theoretical, technical, economic and market potential [8]. The market potential is determined in relation to the real energy needs of customers and the practical possibilities of their implementation. 
For the Silesia Voivodeship, according to [8], there is a possibility of use: approx. 1,5 million square meters of devices area for preparing domestic hot water, as well as approx. 0,5 million square meters of combined systems, allowing to obtain additionally also heat for central heating. The most common for heat obtaining are solar collectors, used in singlefamily residential buildings, as well as public buildings, healthcare or recreational facilities, etc. The growth of market potential and increased interest in such as devices, are significant in the implementation the priorities of sustainable development of the Silesia Voivodeship. It is connected with new, increasingly widely available technologies of efficient solar energy installations, as well as with the possibilities of getting financial support in the implementation of such projects.

At present, as part of the Regional Operational Program of the Silesia Voivodeship for the years 2014-2020 [6], financial support is provided in each of the four subregions, for infrastructure of renewable energy acquisition and distribution and for low-emission economy. In this program [6] there are notations supporting sustainable development through strengthening the economic potential of local development centres, the protection and rational use of environmental resources, energy efficiency support, and the use of local renewable energy potential. The Silesia Voivodeship received the most funds (out of all 16 voivodeships) granted by the European Commission to finance comprehensive projects in the support areas such as: energy efficiency, renewable energy sources and low-emission economy. One of the expected effects of achieving these goals is to increase the amount of energy obtained from renewable sources, including the use of solar energy. [6]

\section{Regional solar conditions}

The characteristic feature of solar radiation energy is high daily, monthly, seasonal and annual variability. The changes of solar radiation quantity delivery are obviously affected by the seasons and latitudes, as well as surface inclination at an angle to the level too. The solar radiation passing through the atmosphere is weakened and reaches the surface as direct radiation or indirect radiation (meaning diffuse or reflected). The sum of all components is global solar radiation, direct and diffused radiation is referred as total radiation. The most important, for energy acquisition, is the direct radiation, but with heavy cloudiness, or strong atmospheric pollution, or during the winter, the part of diffuse radiation increases and become the main form of energy supply radiation [9].

The amount of solar radiation on a square meter - irradiance is measure of instantaneous power, but irradiation is measure of energy of total solar radiation in a given period of time. The southern part of Poland is characterized by a greater amount of available solar energy radiation than other parts of the country, it is associated with the angle of sunlight and the length of the day. Irradiation for the Silesia Voivodeship is about $1000 \mathrm{kWh} / \mathrm{m}^{2}$ [9].

Local measurements of solar radiation factors in a specific place, may create some kind of difficulties, if they were to be implemented individually by a particular user of a local solar installation, and therefore they are rarely realized by them. Therefore, it is advisable to use credible works of special institutions (such as e.g. Research Institutes) that carry out reliable, long-term studies of various climatic factors, including solar radiation parameters among them. The use of these data, made available by the institutes, allows to estimate the potential of solar radiation in particular parts of Poland.

An extensive set of parameters, describing typical meteorological years and statistical climate data, for many locations in Poland, based on the databases of the Institute of Meteorology and Water Management - National Research Institute (IMGW-PIB) [10], from the years 1971-2000, is presented by Ministry of Infrastructure (MI) [11]. It contains sums of total, direct and diffused irradiation, as well as values determined for different angles of inclination, and for different sides of the world. 
The Photovoltaic Geographical Information System (PVGIS) [12], is a similar available source of data, which also contains sums of solar irradiation on a horizontal plane and oriented at different angles. The collection includes a database created on the basis of measurements from the years 1998-2011, and also the new base 2007-2016.

From both databases, MI-IMGW and PVGIS [11, 12], values describing solar radiation parameters were obtained for four places in the Silesia Voivodeship, situated in particular subregions: Bielsko-Biała (Southern subregion), Częstochowa (Northern subregion), Katowice (Central subregion) and Racibórz (Western subregion). In Fig.2. a comparison of monthly sums of total solar irradiation for four locations is presented, chosen as example from the extensive analysis carried out, but not included in the article.
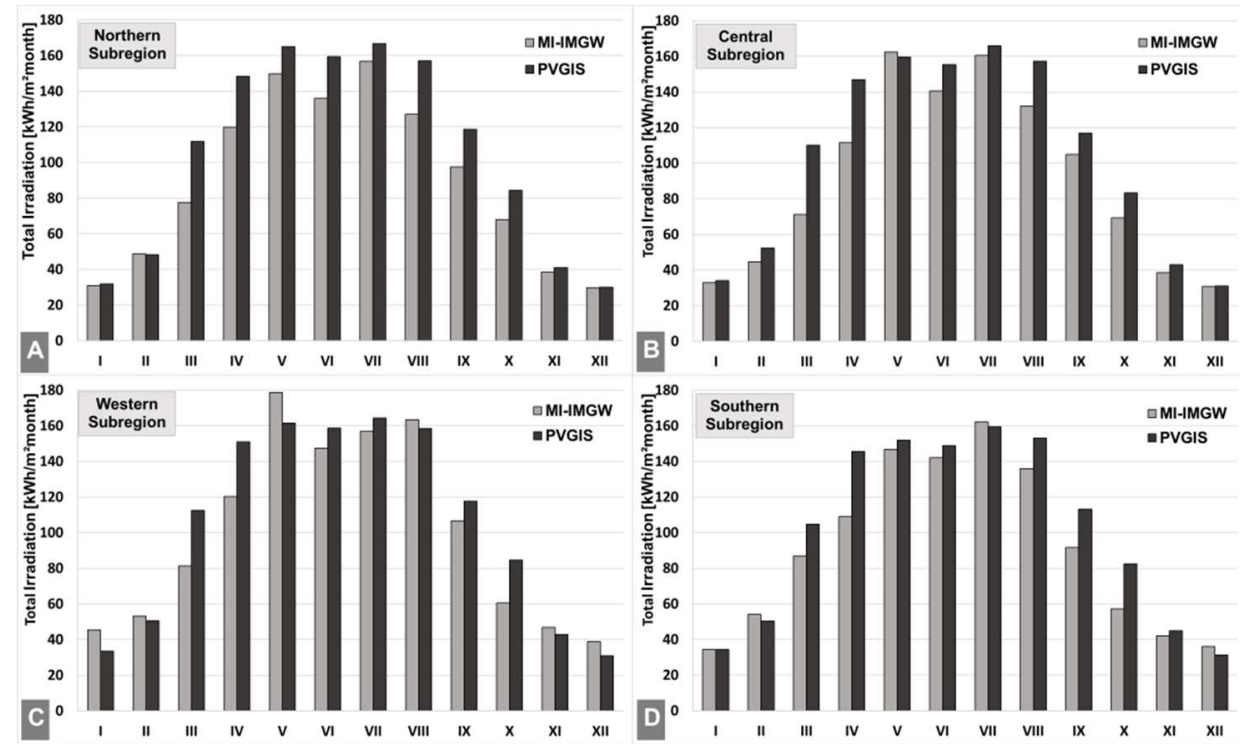

Fig. 2. Sums of total solar irradiation, at selected locations, in each subregion: A - Northern, B - Central, C - Western, D - Southern / own study based on data comparison from [11] and [12].

The specificity of solar conditions in the entire Silesia Voivodeship is similar. However, according to data from PVGIS [12], the Western subregion represented by Racibórz, as well as the Northern subregion with Częstochowa, is characterized by slightly more advantageous solar conditions, relative to other areas. Similar relations occur in the so-called the summer half-year, from April to September, hence there can expect a greater energy production through the use of installations operating only seasonally.

The real placement of solar energy devices is usually realized in a certain angle of inclination from the level. In summer solar energy acquisition is more effective at lower device inclination angles, while in winter it is advisable to set devices at a higher inclination angle to the level. Changes in the device settings are unfortunately rarely used in installations, due to high costs, therefore in the Silesia Voivodeship, for the year-round effective work of units, the use of $35^{\circ}$ angle is suggested [12]. However, if a specific solar installation is used only periodically, then it is recommended to choose the optimal angle of the devices position, designated for this period of the year or season. Fig.3. presents a comparison of the total solar irradiation sums for the four subregions, determined for the plane inclined at an angle of $35^{\circ}$ and directed to the South. Comparing the values for each months and locations, it can be noticed that the irradiations from the PVGIS base [12], compared to those given in MIIMGW [11], are usually higher and more regular, and the anomalies occurring for example in June are smaller. 


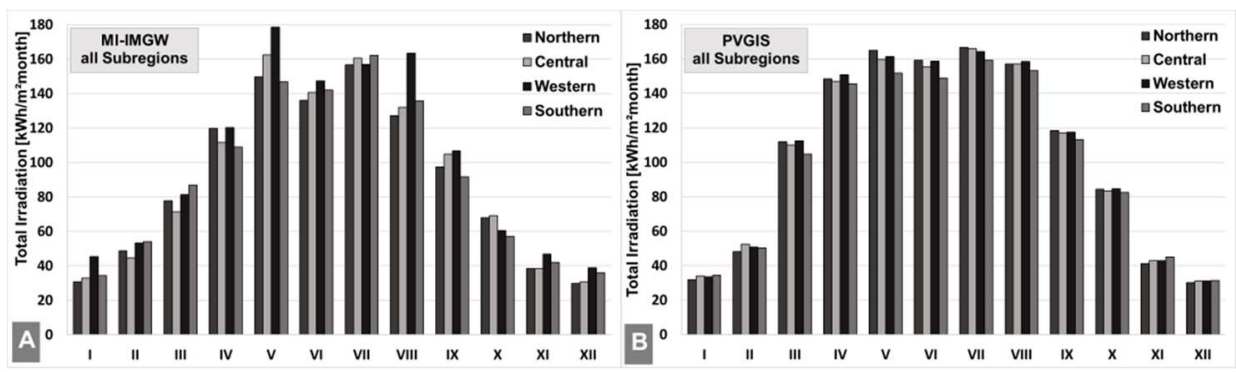

Fig. 3. Comparison of total solar irradiation sums at the all subregions, optimal angle and South direction / own study based on data from $\mathbf{A}$ [11], B [12].

The used databases were created from measurements carried out in different years, in consecutive periods, hence the discrepancies in their comparison may indicate some changes in the solar conditions, as well as possible changes in the local climate.

An additional parameter, that characterizes the solar radiation at a given place, is the sunshine duration, describing the number of hours of direct solar radiation during the day, month or year. The average value of annual sunshine duration in Poland is 1650 hours [9]. The Climate Maps of Poland and the Solar Condition Atlas, created by IMGW-PIB [10], during many years of measurements of selected meteorological elements, show that there are significant sunshine duration differences across Poland. Over the past 40 years, the gradual climate warming up has been observed, especially in the Silesia Voivodeship [10]. This area is shaped by natural and anthropogenic factors, resulting from the intensive urbanization of the area. The upward trend in changes of solar conditions is illustrated by increasingly occurring anomalies. For example, in 2015, according to [10], in the Silesia Voivodeship the large differences of sunshine duration, reached even to 400-500 h, compared to the average values from the years 1971-2000, defined as 1400-1600 $\mathrm{h}$ for this region. Analysing the possibilities of energetic use of the solar radiation potential, it should be remembered, that high sunshine duration does not unequivocally increase the intensity of solar radiation, because it also depends on the angle of incidence of rays and the specificity of the location.

\section{Limitations of solar conditions}

The solar radiation can be used by its conversion, providing useful heat or electricity. Using active methods of obtaining energy it is necessary to take an appropriate methods and equipment. Their efficiency is clearly determined by the amount of solar radiation, too. In order to increase the heat output or electricity in the system, designers and investors are choosing more technologically advanced solutions. Vacuum tube collectors, as opposed to flat collectors, allows to obtain wider range of solar radiation, expanded by the possibility of using the diffused radiation [13]. However, the best class of device does not fulfil its task, when the solar irradiation is not sufficient to meet the energy needs for objects.

The solar energy resources depend on the local terrain, the local climate, but mainly on the quality of the atmospheric air. Areas with large population, on which industrial activity is carried out, including the Silesia Voivodeship, are often characterized by specific climate conditions, that are loaded by air pollutants, which can cause disturbances in the balance of solar radiation. Air pollution is caused by anthropogenic emissions from surface sources (municipal), point sources (professional power industry, technological processes) and linear emissions (transport) [14].The local air pollution can weaken the solar radiation even by $30 \%$, and in winter up to $50 \%$ [9]. 
The quality of the air depends also on the interaction of meteorological conditions and local pollutants emitted into the atmosphere. Particulate matters in the atmosphere are small impurities with different properties, composition and density. They are often transported far away from the sources of their formation and can cause significant disturbances in the solar radiation balance. For example: carbon, present in the form of soot, black carbon, absorbs solar radiation in a wide range of wavelengths, while volatile ash fractions, as bright particles with sulphur and nitrogen content, scatter solar radiation [15].

Dust in the air acts directly on the solar radiation by scattering and absorption, as well as indirectly affecting the formation of clouds, which are the barrier to the direct radiation. Clouds formed in polluted air reflect much more sunlight and may additionally absorb solar radiation. Variability of particulate matter concentrations results from many complex physical and chemical processes, which are influenced by meteorological factors including solar radiation. There are also smog episodes when high solar radiation initiates photochemical reactions. So, there is two-sided interaction between pollution and solar radiation [9].

Intensified problems, related to exceeding air quality standards, concern mainly separated fractions of particulate matter PM10 and PM2,5. Sizes of these parameters in the Silesia Voivodeship are dominant in the country, and are characterized by the highest number of exceedances of limit values $[14,15]$ Unfortunately, this applies to the entire region and the largest population exposed to excess pollution concentrations, especially during the so-called local episodes.

In the Report of Inspectorate for Environmental Protection - The state of the environment in the Silesia Voivodeship in 2016 [14] (report from 2017 is not yet available) it was determined, that the main sources of pollutant emissions to the atmosphere, in the Silesia Voivodeship, was the surface emission, low emission - participation of 59\% for PM10 and $68 \%$ for PM2,5. Also, the inflow emission, coming from outside the voivodeship, from the zone of about $50 \mathrm{~km}$ around the border, was determined as $47 \%$. The emission of particulate air pollutants, in the Silesia Voivodeship, was accounted for $23,6 \%$ of the national emissions of dust, unfortunately, the most prevalent were pollution from fuel combustion, in quantity $37 \%$ of the total dust emission in the voivodeship. But in comparison with 2015, however, there was a decrease in dust emissions by $10,5 \%$ in the Silesia Voivodeship [14].

In accordance with data, obtained from extensive measurements, conducted by the Provincial Environmental Protection Inspectorate in Katowice [16], as part of the Air Quality Monitoring System, for example in 2017, monthly particulate matter PM10 concentrations in the Silesia Voivodeship, were characterized by significant exceedances of the limit value of $40 \mu \mathrm{g} / \mathrm{m}^{3}$, mainly during the heating season, as shown in Fig.4A. There was also a large variation in the value of this parameter in individual parts of the Silesia Voivodeship. The most unfavourable conditions, with the largest exceeding of the admissible values, were noticeable for the Western subregion.

In Fig.4B. a comparison of concentrations of PM10 in subsequent years for this subregion is presented. Analogically, the highest dust contents were in autumn-winter as well as in winter-spring period, when the heating of buildings was carried out by using conventional sources for energy production. However, it is necessary to pay attention to large discrepancies in the PM10 particulate matter content in particular years and months, especially during the heating seasons. Therefore, the distribution of dust pollutants in the air, due to its specificity and lack of repeatability, should be considered only on the basis of continuous local measurements, which are now increasingly available online in relevant applications. Significant reduction in the availability of solar energy in a region, can be caused by dust content in the atmosphere, but also high instability of meteorological conditions and occurring more often significant weather anomalies. 

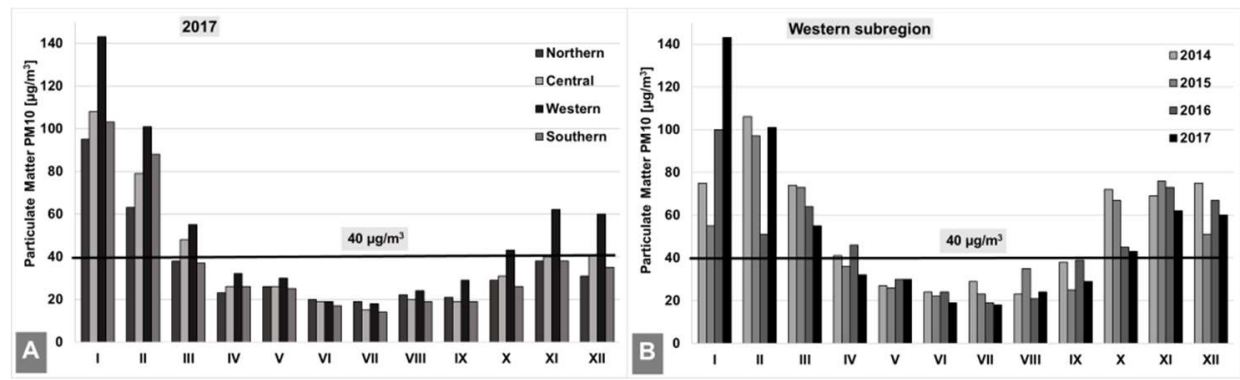

Fig. 4. Comparison of particulate matter PM10 concentrations, A - for all subregions, B - for Western subregion in subsequent years / own study based on data from [16]

The largest exceeding of the admissible values of PM10 concentrations, in the Silesia Voivodeship, are noticeable unfortunately for the Western subregion, which paradoxically, is characterized by an advantageous base solar energy potential. High dust content in the air in this region, however, can greatly destabilize solar conditions and limit the availability of solar radiation, as well as affect the possibility of obtaining energy. The specificity of radiation actually reaching the ground surface changes. Due to the strong pollution of the atmosphere, only diffuse solar radiation (which together with direct solar radiation gives total solar radiation), can be a useful component of the radiation that supplies energy. In Fig.5. relationship between total and diffuse solar radiation in the Western subregion is presented.
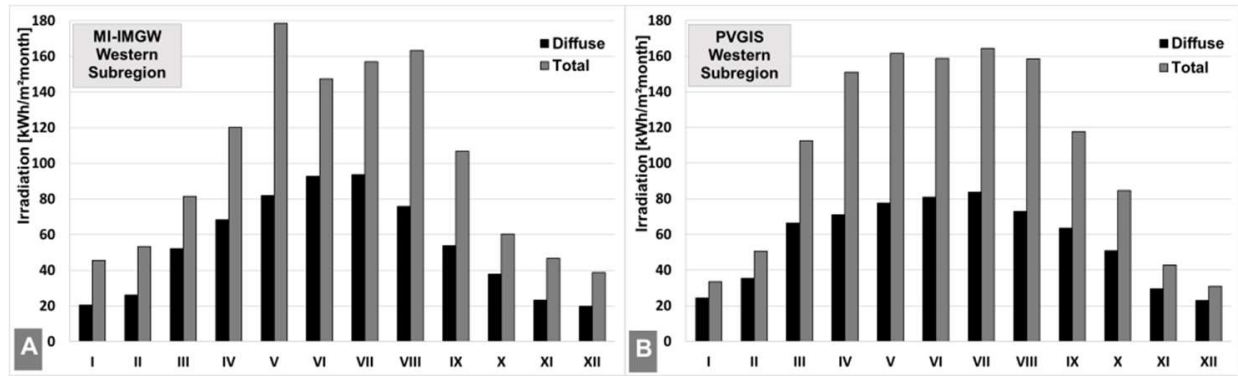

Fig. 5. Comparison of irradiation from total solar radiation and diffuse solar radiation in Western subregion / own study based on data from A [11], B [12].

At the same time, dust particles deposited directly on the devices, in the absence of cleaning and current maintenance activities, can also significantly reduce the efficiency of solar energy devices. Therefore, for efficient use of solar conditions, it is extremely important to improve air quality by reducing pollutant emissions and reducing particulate matters concentrations.

The deposition of dust on devices is also influenced by many other factors such as precipitation (type, size, time of operation), wind (direction and speed) and other elements whose distribution, intensity and repeatability are varied in the region. However, no further interpretation of this issue was carried out, because this was not the subject of the current analysis.

\section{Corrective action}

In order to improve the air quality in the Silesia Voivodeship, many preventive and corrective actions are currently being implemented, which are consistent with the priorities of sustainable development of the region.

In April 2017, the Anti-smog Resolution [17] was adopted, and in January 2018 the "Silesia under the blue sky" contract was concluded with the National Centre for Research 
and Development. It assumes support for projects aimed at reducing the level of air pollution in the region, i.e. works leading to innovation in environmental technologies, low-emission technologies and enabling effective and economical management of resources, including the promotion of obtaining energy from renewable sources.

To developing innovative solutions to problems in the area of sustainable development was allocated 100 million zloty, as part of the Regional Operational Program [6], and the Intelligent Development Operational Program [18].

The next action is the Air Protection Program (update - December 2017) [19], it concerns the Silesia Voivodeship parts, in which excessive concentrations of substances in the air have been found. Its goal is to achieve levels of acceptable substances in the air and improve its quality.

Ventures allowing to reduce low emissions are, for example: liquidation of coal-fired boilers, modernization of heat sources in individual buildings (implemented as part of dedicated low-emission reduction programs), thermomodernization of multi-family residential buildings, etc. [14] In addition, the promotion of the use of renewable energy sources, including the acquisition of solar energy for using, for example, solar collectors.

Care for air quality, in areas exposed to pollution exceeding the standards, enforces the use of additional system solutions, such as conducting a balanced policy in the field of spatial planning.

There is a close relationship between the occurrence of exceedances of permissible concentrations of substances with emission of pollutants, meteorological conditions, terrain, physical and chemical changes occurring in the air, and also with the lack of ventilation, which causes deterioration of the possibility of pollutants dispersing [19]. Therefore, to improve climatic comfort in highly urbanized areas, it is necessary to implement adaptation plans with the so-called ventilation channels, which allow the city's breathability, the ability to regenerate the air [14].

The successive exchange of air masses significantly reduces the possibility of accumulation of pollutants, hence the activities of this kind allow in consequence to improve the transparency of the atmosphere, and increase the access of solar radiation reaching potential energy-generating devices.

\section{Conclusions}

Meeting the rising energy demands in the various spheres of life activities often has an negative impact on the environment and causes a huge permanent changes in it. To prevent this, the priorities of sustainable development are currently being realised in the Silesia Voivodeship, including implementation of renewable energy and low-emission economy, placed in many documents, such as development strategies, operational programs, etc. In promoting renewable energy sources, attention is paid to using the potential of solar energy.

According to data obtained from two sources: MI-IMGW [11] and PVGIS [12], from the presented comparison carried out for individual four selected regions, it follows that the specificity of solar conditions in the whole of the Silesian Voivodeship is similar. However, the Western subregion is characterized by slightly more favourable solar conditions relative to other areas, which is particularly visible during the summer half-year.

Comparing the values for individual months and locations, it is noticeable that the solar radiation parameters from the base MI-IMGW (obtained from years 1971-2000), with reference to PVGIS (1998-2011 and 2007-2016), are usually lower and are characterized by greater irregularity. Higher and more regular data from the PVGIS database can be evidence of changes in solar conditions over the years, as well as changes in the local climate. However, determining of the location with dominant solar conditions it is not unambiguous due to their variability in particular ranges of the year. 
In the selected Western subregion (satisfactory due to the most favourable solar conditions), unfortunately, there is the highest content of dust in the air. This is evident in winter and spring, as well as in autumn and winter, when heating buildings takes place using conventional sources for energy production. There are also noticeable discrepancies in the PM10 particulate matter content in particular years and months.

Due to the extensiveness of the subject, the exemplary methodology of statistical forecasting of the insolation size depending on the dust concentration size has not been presented. It is a complex and multi-variant problem, mainly due to the high volatility and lack of repeatability of conditions. It may also include a significant number of additional factors interacting with each other, such as temperature and humidity, wind speed and direction, precipitation (rain, snow) etc.

However, the Provincial Environmental Protection Inspectorate in Katowice (WIOŚ) [16], in cooperation with The Institute of Meteorology and Water Management - National Research Institute (IMGW-PIB) [10], makes available current Air Quality Monitoring maps, as well as extensive materials of the Air Quality Prognosis System in the Silesia Voivodeship.

In the case of solar conditions it is obvious lack of repeatability for individual days, seasons, months, or years, and also because of various weather conditions and climate. However, the solar conditions in the Silesia Voivodeship, create a chance for their effective use as a potential source of heat and electricity. Expanding the market for renewable energy sources can be implemented by introducing, for example, low power systems with photovoltaic cells to obtain electricity, or installations with solar collectors for the preparation of domestic hot water or central heating support.

Due to the specifics of the Silesia Voivodeship, the influence of factors such as air pollution locally emitted to the atmosphere or coming from other areas, or local episodes affecting air quality and thus limiting the availability of solar radiation, cannot be ignored. Noteworthy are also weather anomalies. All these elements can significantly distorted local solar conditions. Dissemination of installations using solar radiation, in addition to acquiring energy, also gives the opportunity to reduce the regional emission of pollutants into the air and at the same time increase the transparency of the atmosphere.

However, the realization of sustainable energy development, the implementation of renewable energy sources and the low-emission economy in Silesia Voivodeship can contribute significantly to the improvement of air quality and thereby improve the availability of solar radiation.

The introduction of appropriate activities in the region, which are part of the implementation of the principles of sustainable development, may contribute to increasing the real availability of local solar potential, enabling more efficient energy acquisition, as well as reducing the adverse impact of air pollution on the health of residents, as it should not be forgotten, that solar radiation is also a very important factor affecting the well-being and psychophysical condition of a human being.

The material was prepared as part of statutory research of the Czestochowa University of Technology BS/PB-407-302/11

\section{References}

1. K. Prandecki, Teoretyczne podstawy zrównoważonej energetyki, Econ. Stud., 166 (2014)

2. WCED, Our Common Future, Oxford University Press, Oxford (1987)

3. E. Lorek, Inteligentny $i$ trwaty rozwój warunkiem wzmocnienia konkurencyjności regionu ślaskiego, J. Econ. and Envir. 3 (58) (2016)

4. GUS, (2018), http://www.stat.gov.pl

5. PLAN, Plan Zagospodarowania Przestrzennego Województwa Ślaskiego 2020+ http://www.slaskie.pl/planzagospodarowania/ 
6. RPO WSL, Regionalny Program Operacyjny Województwa Śląskiego na lata 20142020, https://rpo.slaskie.pl/

7. STRATEGIA, Strategia Rozwoju Województwa Ślaskiego, ŚLĄSKIE 2020+, http://www.slaskie.pl/zalaczniki/2013/07/04/1372921202/1372921250.pdf

8. G. Wiśniewski (red.), Określenie potencjału energetycznego regionów Polski w zakresie odnawialnych źródet energii, Ministerstwo Rozwoju Regionalnego, Warszawa (2011)

9. E. Wołoszyn, Meteorologia $i$ klimatologia $w$ zarysie, Wydawnictwo Politechniki Gdańskiej, Gdańsk (2009)

10. IMGW-PIB, http://klimat.pogodynka.pl

11. MI, http://mib.gov.pl/2-Wskazniki_emisji_wartosci_opalowe_paliwa.htm

12. PVGIS, http://re.jrc.ec.europa.eu/pvgis.html

13. J. Rudniak, Lokalne zasoby energii promieniowania stonecznego a eksploatacja kolektorów, COW 7/47, 270-276 (2016)

14. IOŚ, Stan środowiska w województwie ślaskim w 2016 roku, Bibl. Monitor. Środ., Katowice (2017)

15. K. Juda-Rezler, B. Toczko (red.), Pyty drobne w atmosferze, Bibl. Monitor. Środ., Warszawa (2016)

16. WIOŚ, System monitoringu jakości powietrza, http://powietrze.katowice.wios.gov.pl/

17. UA, Uchwała antysmogowa sejmiku województwa śląskiego, $\mathrm{nr} \mathrm{V} / 36 / 1 / 2017$ https://powietrze.slaskie.pl/content/uchwala-sejmiku-nr-v3612017

18. POIR, Program Operacyjny Inteligentny Rozwój na lata 2014-2020, https://www.poir.gov.pl/media/48312/Program_aktualizacja_2017_vs2.pdf

19. POP, Program ochrony powietrza dla terenu województwá ślaskiego majacy na celu osiagnięcie poziomów dopuszczalnych substancji w powietrzu, Katowice (2017)

http://www.slaskie.pl/zalaczniki/2017/12/27/1514373867/1514373995.pdf 